\title{
Synopsis Articles in the Planning of a Trilingual Dictionary: Yilumbu- French-English
}

\author{
P.A. Mavoungou, Department of Afrikaans and Dutch, University of \\ Stellenbosch, Stellenbosch, Republic of South Africa \\ (13126733@humarga.sun.ac.za)
}

\begin{abstract}
A distinction is often drawn between single articles and synopsis articles. A single article is the so-called default article. It does not deviate from the traditional microstructural approach of the dictionary because it presents the minimum data for each lemma sign treated, while a synopsis article gives additional data for each treated lemma. The classical conception of the synopsis article originates with Bergenholtz, Tarp and Wiegand (1999). In their view, synopsis articles which were devised for language for special purposes (LSP) dictionaries have to make provision for the treatment of lemma signs functioning as superordinate terms (general lemmata or topics) as well as their hyponyms. The aim of this article is to present a new lexicographic approach to the study of synopsis articles against the background of a planned trilingual dictionary. It will be shown that synopsis articles have a more general use than its restricted application in LSP dictionaries. In fact, the focus will not be on the treatment of technical or scientific vocabulary but rather on cultural terms. This article also raises among other things, questions about the purpose of the planned dictionary, its target users, different types of microstructures as well as different data categories to be included in synopsis articles.
\end{abstract}

Keywords: SYNOPSIS ARTICLE, SINGLE ARTICLE, DIFFERENT TYPES OF MICROSTRUCTURES, LEMMA SIGN, LINGUISTIC AND EXTRA-LINGUISTIC ASPECTS, LSP DICTIONARIES, TARGET GROUP, DATA CATEGORIES, CULTURE-BOUND LEXICAL ITEMS, SPECIALFIELD TERMS

Abstract: Articles synopsis dans la planification d'un dictionnaire trilingue: yilumbu-français-anglais. Une distinction est souvent faite entre articles simples et articles synopsis. L'article simple est encore connu sous la dénomination d'article par défaut. Il ne dévie pas de l'approche microstructurelle traditionnelle du dictionnaire parce qu'il présente le minimum pour chaque lemme traité, alors qu'un article synopsis offre des données additives pour chaque lemme traité. La conception classique d'article synopsis est de Bergenholtz, Tarp et Wiegand (1999). De leur point de vue pour les articles synopsis qui ont été conçus pour des dictionnaires de langue de spécialité (LSP), des dispositions doivent être prises pour le traitement de signeslemmes fonctionnant comme termes superordonnés (lemmes généraux ou thèmes) ainsi que leurs hyponymes. L'objectif de cet article est de présenter une approche lexicographique nouvelle pour l'étude des articles synopsis avec en toile de fond un dictionnaire trilingue en proposition. Il sera montré que les articles synopsis ont un usage plus large que leur application limitée aux dictionnaires LSP. En effet, le centre d'intérêt portera non pas sur le traitement des termes du vocabulaire 
technique ou scientifique mais plutôt sur des termes culturels. Cet article soulève également entre autres choses des interrogations quant à la visée du dictionnaire proposé, ses utilisateurs cibles, les différents types de microstructures ainsi que les différentes catégories de données à inclure pour chaque article synopsis.

Mots-clés: ARTICLE SYNOPSIS, ARTICLE SIMPLE, DIFFÉRENTS TYPES DE MICROSTRUCTURES, SIGNE-LEMME, ASPECTS LINGUISTIQUES ET EXTRA-LINGUISTIQUES, DICTIONNAIRES LSP, GROUPE CIBLE, CATÉGORIES DE DONNÉES, ITEMS LEXICAUX CENTRÉS SUR LA CULTURE, TERMES TECHNIQUES

\section{Introduction}

According to Hausmann and Wiegand (1989: 340), the microstructure of a dictionary article is the total set of linearly ordered information items following the lemma sign. As far as this point is concerned, a distinction is drawn between single articles and synopsis articles. A single article is the so-called default article. It does not deviate from the traditional microstructural approach of the dictionary because it presents the minimum data for each lemma sign treated, while a synopsis article gives additional data for each treated lemma sign. Moreover, some synopsis articles will focus on linguistic aspects but others will go further including extra-linguistic aspects.

The classical conception of synopsis articles originates with Bergenholtz, Tarp and Wiegand (1999). According to their view, synopsis articles which were devised for language for special purposes (LSP) dictionaries, have to make provision for the treatment of lemma signs functioning as superordinate terms (general lemmata or topics) as well as their hyponyms. In this article an innovative lexicographic approach to the study of synopsis articles is proposed. Before discussing this proposition however, the purposes, nature and typology of the planned trilingual dictionary, Yilumbu-French-English, will be offered.

Guthrie (1953) classifies Yilumbu as B. 44, which falls in the same language group as Ghisira (B. 41), Yisangu (B. 42) and Yipunu (B. 43). It is a Bantu speech form spoken in Gabon and in its neighbouring countries, the Republic of the Congo and the Democratic Republic of the Congo.

In Gabon, Yilumbu speakers mostly reside in two of the nine Gabonese provinces, namely Nyanga (especially in Mayumba) and Ogooué-Maritime (especially in Gamba and Setté-Cama). This geographical distribution has led to the existence of two major dialects: Yilumbu yi ghângu (the variety of the Nyanga province) and Yilumbu yí menaáne (the variety of the OgoouéMaritime province) $)^{1}$.

Although the main focus of this article is on the microstructure of the planned dictionary, a variety of lexicographic data regarding the addressing structure, the access structure, the mediostructure, the data distribution structure as well as some aspects of the user perspective will necessarily come into play. 


\section{The purpose, functions, nature and typology of the planned dictionary}

It is a well-attested fact that the genuine purpose (cf. Wiegand 1999: 299) of a particular dictionary should be identified prior to the compilation phase and provision to fulfil the real needs and reference skills of the intended target users should be made. At this stage the genuine purpose of the planned dictionary can be described as follows: On account of the decoding and encoding functions, the planned dictionary should assist native- and foreign-language speakers on an equal basis in retrieving relevant information as quickly as possible. More specifically, the planned dictionary should fulfil two main functions. These are: (a) A dictionary for the Balumbu helping them to understand Yilumbu texts. (b) A dictionary for the Balumbu helping them to produce Yilumbu texts. Moreover, the planned dictionary will be a typological hybrid (cf. Gouws 1999: 39) in the sense that it will have features of both translation and monolingual dictionaries. As far as monolingual features are concerned, the planned dictionary will provide users with a brief paraphrase of the meaning of the lemma sign in the source language (Yilumbu). This paraphrase of meaning can be expanded for the compilation of a comprehensive version of the dictionary. With regard to translation features, the planned dictionary will present translation equivalents for lemmata where available. The low-density orientated microstructure will give the work the features of a pedagogical dictionary. In other words, by presenting the data as explicitly as possible the planned dictionary could be used by high school pupils, students and learners. With regard to the interaction between users' needs and dictionary typology, the planned dictionary will be a typological hybrid in the sense that it will also include special-field terms. Finally, the inclusion of data regarding the protoBantu reconstruction of the genuine Yilumbu lemma signs as well as the source language items for Yilumbu loan words will give the planned dictionary all the features of both historical and etymological dictionaries.

\section{The synopsis article: A new conception}

As stated above, synopsis articles were devised for dictionary articles displaying a variety of lexicographic data that could not fit into the so-called single article. Given the fact that a certain category of lexical items require more data than the traditional treatment to be allocated to the average lemma sign, Bergenholtz, Tarp and Wiegand (1999) argue in favour of a category of articles, which will focus on extra-linguistic aspects, the traditional encyclopedic approach. According to Gouws (1999: 41), typical items to be treated in synopsis articles are scientific words used in general conversation between expert and lay person, e.g. medical and juridical terminology.

Language for special purposes, although very important, may not be regarded as the only field of application for synopsis articles. In other words, it is believed that synopsis articles have a more general use than its restricted 
application in LSP dictionaries. In fact, the focus will not be on the treatment of technical or scientific vocabulary but rather on cultural terms. More specifically, priority will be given to the treatment of lexical items with a high degree of cultural information. One of the representatives of these lexical items is the so-called "culture-bound lexical items". According to Tomaszczyk (1984: 289), "culture-bound lexical units include items which represent objects, ideas and other phenomena that are truly unique to a given speech community. In the pursuit of this definition it should be emphasised that culture-specificity is merely a matter of degree". This is particularly relevant because the culturebound lexical items in question have to be regarded as cross-cultural lexemes in the African languages ${ }^{2}$ in general and the Gabonese languages in particular, although they, to a greater or lesser degree, throw light on some aspects of the typical socio-cultural background of the Yilumbu lexicon. With regard to macrostructural selection the following criteria will apply: without necessarily working with the idea of superordinate versus hyponym as in Bergenholtz, Tarp and Wiegand (1999), lexical items of the same genus and other scientific terms as well as cultural terms will be included. The dictionary conceptualisation plan (cf. Prinsloo and Gouws 2000: 153) should therefore provide a data distribution structure which warrants a differentiated approach with regard to the structure of the dictionary articles. The point here is threefold. Instead of using inserted inner texts, some articles (especially those presenting a lemma sign representing a high degree of cultural information) will have, according to the specific case: (a) a cultural or encyclopedic section presenting texts in the three languages of the dictionary (Yilumbu-French-English), (b) a cultural or encyclopedic section presenting texts in only the target languages of the dictionary (French-English), and (c) a cultural or encyclopedic section presenting excerpts from relevant literature dealing with the lexical items treated. The foregoing also applies to dictionary articles dealing with a general discussion of special-field terms: the classical conception of synopsis articles.

This wider application is important, because dictionary articles do not have to be treated alike. The concept of synopsis articles is used here as the venue or landing spot ${ }^{3}$ for the treatment of ethnographical terms. This will also give the planned dictionary features of the so-called "ethnographical dictionary". According to Zgusta (1987: 14), an ethnographical dictionary is "a dictionary that tries to describe a culture in the entries of the single relevant words". In addition, these synopsis articles may be qualified because articles with the encyclopedic section presented in the three languages of the dictionary may differ from one with a bilingual presentation or even with one merely containing a comment on pragmatics following the linguistic presentation. This difference in presentation may be motivated on account of culture specificity as well as the subject knowledge of the users. This discrepancy in the treatment should also be explained in the user's guide. User proficiency will furthermore determine the nature and extent of the lexicographic presentation. For example, in the case of surrogate terms ${ }^{4}$, speakers of English and French may need more 
cultural information than mother-tongue speakers of Yilumbu because for the latter a certain degree of familiarity with the treated surrogate terms will be assumed. These metalexicographic foundations have to be entered in the front matter of the specific dictionary. Moreover, according to Gouws (1999: 42), "the back matter could also contain a text with a list of all the items which are treatment units in the central list's synopsis articles". As will be shown later in this article, the microstructural treatment in synopsis articles is open to a variety of classes. Therefore, if not planned carefully, the microstructural arrangement of the dictionary articles dealing with these lexical items may create communicative problems for the target users of the specific dictionary. It may be worthwhile to devote some space to this important aspect of the dictionary conceptualisation phase.

\section{The target group}

Any dictionary project should clearly identify its target users prior to the compilation phase. The target users of the dictionary under discussion range, on the one hand, from senior high school pupils to academics who have Yilumbu as first language and a relative good command of French or English, and, on the other hand, pupils and scholars who want to improve or learn Yilumbu as second language. That at this stage no dictionary for special-field terms exists in Yilumbu (in fact, there is no Yilumbu dictionary at all) is a motivation for the inclusion of technical vocabulary. With regard to the question of how many languages for special purposes should be included, the intention is that the planned dictionary should include special-field lemmata from among others astrology, agriculture and traditional pharmacopoeia. These three special fields are not arbitrarily motivated but is based on empirical observation. In fact, people use medical, astrological and agricultural terminologies on a daily basis. With regard to the extent to which technical vocabulary should be treated, it should be made clear that the data presented are not intended for specialists but for laypersons. Obviously, there is a limit to what can be included in a dictionary. Therefore the questions to be addressed are: What can be included? What should be left out, and why? For example, as far as the treatment of plant names is concerned, it has been decided to leave out data such as the scientific description (height and diameter, arrangement and texture of the foliage and leaves, etc.), the distribution and the cultivation requirements of the plant dealt with. This data will be interesting to the knowledgeable reader but of little use to the uninitiated or non-specialist. As far as this data is concerned, the specialist can always be referred to LSP dictionaries and botanical journals. Contrary to this approach, a simplified presentation of the description, habitat and uses of the plant dealt with may be useful to users. Given their relevance as data types, the scientific name as well as the genus of the plants has to be included. However, the metalanguage should be kept as simple as possible. This aspect receives attention once again in a subsequent section of this article. 
In addition, a pictorial illustration may be more accurate than a complete scientific description of the plant name lemmatised. This chiefly depends on the space the publisher is willing to allocate to a trilingual dictionary of this kind that obviously has space constraints. The ideal for this kind of work will be to have a final product combining dictionary and encyclopaedia.

\section{Different types of microstructures}

Hausmann and Wiegand (1989: 354) distinguish three types of microstructures, namely: integrated microstructures, partially or semi-integrated microstructures and unintegrated microstructures. According to their approach (Hausmann and Wiegand 1989: 346), a dictionary article displays an unintegrated microstructure when the items indicating semantic data and the items giving idioms and the competence examples are presented in two different subsections, the first subcomment on semantics and the second and further subcomments on semantics respectively. Along the line of Hausmann and Wiegand (1989) but rather focusing on the concept of addressing, Gouws (1999: 47) proposed a reformulation of the unintegrated microstructure:

An unintegrated microstructure displays a distant addressing between a co-text entry and the relevant paraphrase of meaning/translation equivalent. In the case of a lemma sign representing a polysemous lexical item, a bilingual dictionary will give all the translation equivalents and then present the co-text entries, Contrary to the above-mentioned microstructure, an integrated microstructure displays a system of direct addressing between a paraphrase of meaning/translation equivalent and its co-text entry/entries. Each paraphrase of meaning/ translation equivalent is immediately followed by the co-text entry illustrating the typical usage of the lexical item in question.

This is clear from Text examples 1 and 2.

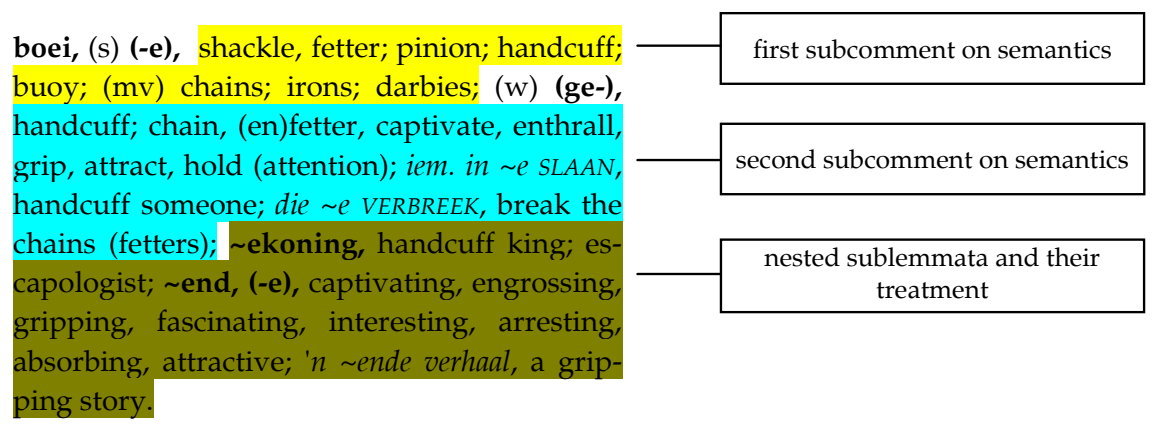

Text example 1 (from Groot Woordeboek, 198613: 97). ${ }^{5}$ 
Compilers of the Groot Woordeboek have interpreted the lexical item boei as a lemma sign with more than one part of speech function. In fact, it can function as a noun and as a verb. In the treatment of the article of the lemma boei, the user is provided with a list of translation equivalents (first subcomment on semantics) followed by the item giving the form of the lemma sign functioning as a verb (w) (ge-). The latter is then followed by a list of translation equivalents as well as by collocations (iem. in e SLAAN and die e VERBREEK), illustrating the use of boei functioning as a noun. One may speak of these collocations as a distant addressing because they do not belong to this second subcomment on semantics. They should have been presented under the first subcomment on semantics, before the item giving the form of the lemma sign functioning as a verb. The distant addressing relation existing between co-text entries and their relevant translation equivalents is taken a bit further in the treatment of the sublemmata boei-ekoning and boei-end. After a mere listing of translation equivalents without any indication of the co-text in which they are generally used, the user only gets the entry ' $n \sim$ ende verhaal.

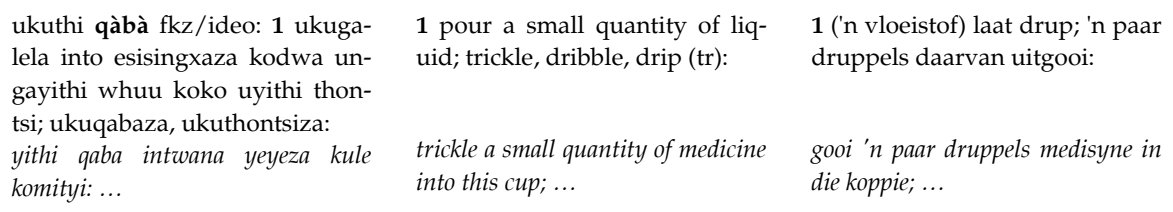

Text example 2 (from the Greater Dictionary of Xhosa, 1989: 1)

The dictionary article above is user-friendly because the compilers have made the typographical presentation of the lexicographic text in such a way that it is clearly perceived by the user. Each paraphrase of meaning is immediately followed by the appropriate illustrative example.

Gouws (1999: 47) describes a semi-integrated microstructure as follows:

A semi-integrated microstructure is a hybrid form displaying features of both an integrated and an unintegrated microstructure and is typically used in more comprehensive dictionaries where lengthier articles with a variety of data types and search zones occur. The article structure has two distinct sections to deal with the two microstructural types, cf. Wiegand (1996). In the first article component, a single co-text entry is added to each entry given as a paraphrase of meaning/translation equivalent. A separate article component is presented to accommodate additional co-text entries. In this unintegrated component the relation between each co-text entry and the relevant paraphrase of meaning/ translation equivalent entry is explicated by means of a clear and unambiguous cross-reference entry marking the co-text entry as addressed at a specific paraphrase of meaning/translation equivalent entry.

This point is illustrated by Text example 3 which is a proposed article structure for the treatment of the lemma fumu. 


\begin{tabular}{|c|c|c|}
\hline \\
\hline 1 Mútu wó avátúmi. & $\begin{array}{l}1\langle\text { F }\rangle \text { Chef, propriétaire (non au } \\
\text { sens légal du terme mais plutôt } \\
\text { au sens d'avoir un privilège } \\
\text { sur ou des responsabilités vis- } \\
\text { à-vis de quelqu'un ou quelque } \\
\text { chose). }\end{array}$ & $\begin{array}{l}1\langle\mathbf{E}\rangle \text { Chief, owner (not in the } \\
\text { legal sense of the word but } \\
\text { rather in the sense of having } \\
\text { privilege over or responsibility } \\
\text { for something or someone). }\end{array}$ \\
\hline$\sum \|$ Fumu anáwiítsa. & $\langle\mathbf{F}\rangle$ Le chef est arrivé. & $\langle\mathbf{E}\rangle$ The chief has arrived. \\
\hline $\begin{array}{l}2 \text { mwâna fumu (aussi/also } \\
\text { (apoc.) mwâ fumu/Fumu) } \\
\text { Mwâna úbura să mwâna my- } \\
\text { óoghu vhó mwâna muvhĭga. }\end{array}$ & $\begin{array}{l}2\langle\mathbf{F}\rangle \text { Personne de sang noble } \\
\text { par opposition à l'esclave. }\end{array}$ & $\begin{array}{l}2\langle\mathbf{E}\rangle \text { Person of noble blood as } \\
\text { opposed to a slave. }\end{array}$ \\
\hline $\begin{array}{l}\sum \| \text { Yá ábanganga fumu ífum- } \\
\text { ba. }\end{array}$ & $\begin{array}{l}\langle\mathbf{F}\rangle \text { Il était le chef de la famille } \\
\text { (par le sang). }\end{array}$ & $\begin{array}{l}\langle\mathbf{E}\rangle \text { He was the head of the fam- } \\
\text { ily (by blood). }\end{array}$ \\
\hline 3 Mútu wó aváwúkígha bátu. & $\begin{array}{l}3 \text { (par ext.) }\langle\mathbf{F}\rangle \text { Rassembleur, } \\
\text { unificateur. }\end{array}$ & $\begin{array}{l}3(\text { by ext.) }\langle\mathbf{E}\rangle \text { Assembler, uni- } \\
\text { fier. }\end{array}$ \\
\hline $\begin{array}{l}\sum \| \text { Mí fumu iwăla myóoghu. } \\
\text { Mo ífumba isăna búrandu. }\end{array}$ & $\begin{array}{l}\langle\mathbf{F}\rangle \text { J'ouvre les bras en signe de } \\
\text { rassemblement. Au sein de la } \\
\text { famille je n'ai pas de parti pris. }\end{array}$ & $\begin{array}{l}\langle\mathbf{E}\rangle \text { I open my arms as a sign of } \\
\text { assembling. In the bosom of the } \\
\text { family I am not biased. }\end{array}$ \\
\hline $\begin{array}{l}4 \text { Fumu (o ingánga) Mwâna } \\
\text { Nzâmbi. }\end{array}$ & 4 (chris.) $\langle\mathbf{F}\rangle$ Le Seigneur. & 4 (Chris.) $\langle\mathbf{E}\rangle$ The Lord. \\
\hline | || Á! Fumu! & $|\mathbf{F}\rangle$ Ah! Seigneur! & $\langle\mathbf{E}\rangle$ Oh! Lord! \\
\hline \multicolumn{3}{|c|}{ 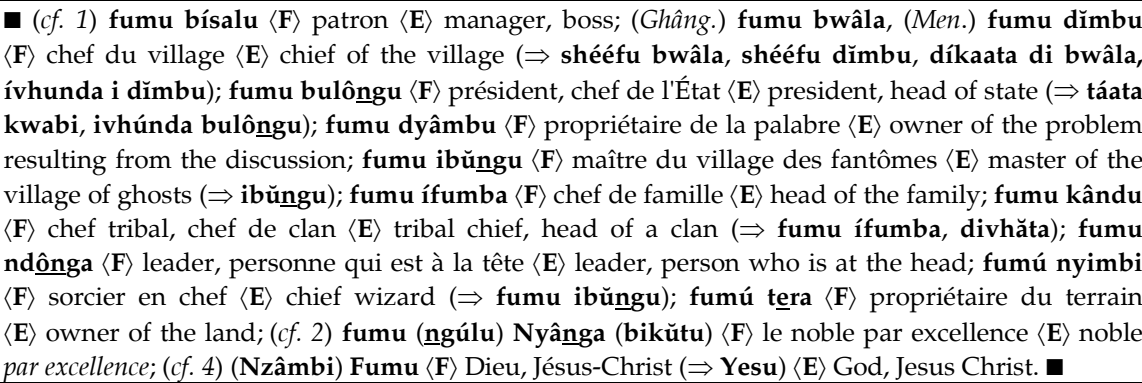 } \\
\hline $\begin{array}{l}\sum \| \text { (Ghâng.) Yabé fumu bwâla } \\
\text { anáwiítsa. }\end{array}$ & $\begin{array}{l}\langle\mathbf{F}\rangle(c f .1) \text { Lui-même le proprié- } \\
\text { taire est arrivé. }\end{array}$ & $\begin{array}{l}\langle\mathbf{E}\rangle(c f .1) \text { The owner himself } \\
\text { has arrived. }\end{array}$ \\
\hline $\begin{array}{l}\sum \text { II Uvárómba úweela vángi } \\
\text { ngébé fumu dyâmbu usăna du- } \\
\text { pátaaghu dumwéégha. Disăsí- } \\
\text { la. }\end{array}$ & $\begin{array}{l}\langle\mathbf{F}\rangle \text { Tu veux te marier mais toi- } \\
\text { même (la personne concernée) } \\
\text { tu n'as pas un seul franc (en } \\
\text { poche). Ça ne se fait pas! }\end{array}$ & $\begin{array}{l}\langle\mathbf{E}\rangle \text { You want to get married } \\
\text { but you yourself (the person } \\
\text { concerned) do not have a single } \\
\text { penny (in your pocket). It } \\
\text { should not be done! }\end{array}$ \\
\hline $\begin{array}{l}\sum \| \text { (Men.) Uyi mbírẹ! Ágho á } \\
\text { fumu. }\end{array}$ & $\begin{array}{l}\langle\mathbf{F}\rangle(c f .2) \text { Il y a l'aigle! Il est le } \\
\text { roi (de tous les oiseaux). }\end{array}$ & $\begin{array}{l}\langle\mathbf{E}\rangle(c f .2) \text { There is the eagle! He } \\
\text { is king (of all the birds). }\end{array}$ \\
\hline \multicolumn{3}{|c|}{ 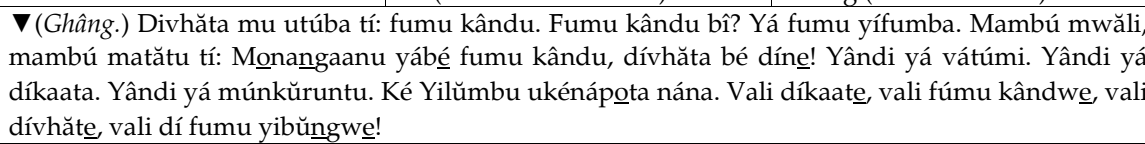 } \\
\hline
\end{tabular}

Text example 3

In the treatment of this article a variety of data types have been presented in four search zones that can be clearly perceived by the user and which display a 
semi-integrated microstructure. The first search area presents the lemma sign followed by its stem, the phonetic transcription item, the part of speech indicator, the item giving the class number as well as the proto-Bantu reconstruction.7 The second search area starting with the Arabic numerals presents a system of direct addressing between the paraphrases of meaning/translation equivalents and their co-text entries. In the third search zone introduced by the symbol $\mathbf{m}$, the lexicographer deals with a paradigm of compounds with fumu as first component. Apart from the compounds fumu (ngúlu) Nyânga and (Nzambi) Fumu, groupings of sublemmata display a strictly alphabetical ordering. Although the lexicographer assists users by clearly indicating which sense of fumu applies to specific lemma clusters, this deviation on alphabetical level is not motivated on semantic or morphological grounds. Therefore this sinuous lemma file may be regarded as an illustration of a second level niching (cf. Gouws 2002: 136). In the fourth section of the article introduced by the symbol $\Sigma \|$, one finds a paradigm of co-text examples displaying an unintegrated microstucture due to the distant addressing prevailing between these lexicographic data and their relevant paraphrases of meaning/translation equivalents that are to be found in section two of the article. In order to anticipate any problem in the retrieval of the information sought by the user, the latter is once again helped by an entry clearly indicating which sense of fumu applies to a specific co-text example. In the fifth search area the treatment proposed is of an ethnographical nature.

\section{Different data categories to be included}

Wiegand (1978 as quoted by Smit 1993: 143-144) takes the view that all parts of the dictionary article, such as the meaning explanations, the items indicating word class, etymology and spelling, can be regarded as answers to specific user questions. These questions that may be anticipated by the lexicographer also determine the dictionary type.

In a dictionary article (cf. Hausmann and Wiegand 1989: 353), the user is usually provided with both macro- and microstructural data. The first data types are referred to as the comment on form (e.g., the lemma sign and the item giving the part of speech) whereas the second data categories are known as the comment on semantics (the paraphrase of meaning/translation equivalent and illustrative material in the form of citations, co-text examples or contextual data). All these data types will be included in synopsis articles.

Below follows more detailed information regarding the inclusion of a few data categories, e.g. paraphrase of meaning/translation equivalent, citation and etymology. In the case of the planned dictionary which is a typological hybrid, it can be assumed that the user will need some meaning descriptions in Yilumbu. The short explanation of the meaning is deliberately written in ordinary language. However, this does not imply that the data presented in the meaning descriptions have to be superficial. As mentioned above, the para- 
phrase of meaning is meant in the first place to improve the abilities of Yilumbu speakers in their own language. The traditional way in explanatory dictionaries is to present meaning explanations without translation equivalents. Such an approach is normal if one considers that monolingual dictionaries are primarily aimed at the description of meaning. However, in bilingual or multilingual dictionaries, although paraphrases of meaning may be included, the priority is not the description of meaning but the co-ordination of source and target language forms. The translation of the paraphrase of meaning and other texts given in the target languages has the genuine purpose (as defined by Wiegand 1999) of giving the adequate translation equivalent to each source-language form. In addition, it may serve as a useful aid in the acquisition of the languages in question by the learners of both French and English and will help to shift the focus from the source language to the target languages (cf. Gouws 1996: 158).

In all existing bilingual dictionaries of the Gabonese languages, coverage is strong on traditional crafts (e.g. fishing, hunting, weaving, pottery, woodcarving, etc.)(cf. Nyangone Assam and Mavoungou 2000). However, citations are hardly ever used and references to relevant literature are seldom found. Citations and references to relevant literature should be included where necessary. These references will provide researchers with additional information when needed. Provision is not made for the inclusion of etymological items explaining from a historical point of view why and how a lexical item has become what it is. That would fall within the scope of a historical dictionary. The inclusion of diachronic data in a synchronic dictionary rather results from the lexicographer's willingness to take both contemporary language and items from former language stages into account.

When the different data categories to be included are discussed, it is also important to comment on their distribution within the dictionary. This is the concern of the data distribution structure which basically determines where the different data categories have to be included. Some data types will make it into the central list, whereas others will be included in the different outer texts of the dictionary (i.e. idioms and proverbs will be included in the back matter section). In addition to the foregoing, provision should also be made with regard to the different search zones within the dictionary articles. It is the task of the data distribution structure to determine the article internal presentation and the different search zones within the dictionary articles. For example, if three data categories have to be included, then the lexicographer has to make provision for three article slots or search zones in the dictionary article.

\section{- Proposed article structures for the treatment of special-field terms}

The dictionary article as shown in Text example 4 has a limited data type. It is clear that the focus is not on linguistic data, e.g. etymology, translation equivalent, etc. but on the field (pharmacopoeia and, to a lesser degree, ethnol- 
ogy). After the items giving the proto-Bantu form of the lemma sign as well as the paraphrase of the meaning, the user is provided with target language entries that are introduced by structural markers, e.g. $\langle\mathbf{E}\rangle$ (for English) and $\langle\mathbf{F}\rangle$ (for French). Co-text entries in the source language are introduced by the symbol $\sum \|$. The English usage example is followed by a text introduced by another structural indicator, namely the black upside down triangle $(\boldsymbol{\nabla})$ used to mark a specific article or search zone in which the user is provided with an additional text or lexicographic description of an encyclopedic or extra-linguistic nature.

\begin{tabular}{|c|c|c|}
\hline \multicolumn{3}{|c|}{ mufúma, mi (+ fuma) [mùfúmə̀] $n$. cl. $3 / 4<{ }^{*}$-fúma or -fứma } \\
\hline \Mwîri múneni o báyisi. & & \\
\hline & & \\
\hline & & \\
\hline \multicolumn{3}{|c|}{$\begin{array}{l}\boldsymbol{\nabla}(\text { Men.) Umábúru mwâna, mwâna muyééyi, ubúkulu mufŭma unééngi mú tseengi. Ubwrsyanga } \\
\text { mwâna, mwâna akúrógha. Kondé kyeeri ágho múru. Ukeba mâmba gho múru, múru ukúróghu } \\
\langle\text { F }\rangle \text { Si tu mets au monde un enfant chétif, prends des écorces du fromager que tu déposes dans une } \\
\text { cuvette. Fais prendre au bébé un bain et il grossira. Toutefois le danger (de ce bain) se situe au } \\
\text { niveau de la tête. Il faut soigneusement éviter de mouiller la tête (de l'enfant) avec l'eau (du bain) } \\
\text { de peur que celle-ci grossisse de façon disproportionnée }\langle\mathbf{E}\rangle \text { If you give birth to a tiny child, take } \\
\text { bark of the kapok tree and put it in a basin. Bath the baby and he/she will grow bigger. However, } \\
\text { the danger (with this bath) lies at the level of the head. Great care should be taken to avoid pour- } \\
\text { ing water onto the (child's) head lest the latter becomes disproportionately big } \Rightarrow \text { quot/cit. }\end{array}$} \\
\hline \multicolumn{3}{|c|}{$\begin{array}{l}\text { Quot/cit }\langle\text { F }\rangle \text { D'après RAPONDA et SILLANS (1961: 106) le tronc (du fromager) sert parfois à faire des } \\
\text { pirogues. Le kapok est vendu dans le commerce. Chez les indigènes, il sert à garnir les coussins et } \\
\text { les matelas ou bien il est filé pour en faire des sacs de voyage. L'écorce des jeunes arbres, débaras- } \\
\text { sée des épines, est usitée pour faire des cloisons de cases. La décoction de l'écorce est employée } \\
\text { comme vomitif ou en lavement. Les feuilles sont émollientes ou calment les névralgies. On tire de } \\
\text { l'huile de ses graines. Ce végétal géant est considéré par les Noirs comme un arbre sacré. Lors- } \\
\text { qu'on voit sur l'emplacement des anciens villages deux pieds de Ceiba côte à côte, c'est l'indice que } \\
\text { là, autrefois, sont nés deux enfants jumeaux. On le plante aussi comme arbre principal du fétiche- } \\
\text { protecteur ou sur les tombes. C'est au pied de ces arbres que l'on dépose les offrandes faites aux } \\
\text { mânes des ancêtres ou aux génies tutélaires. }\end{array}$} \\
\hline \multicolumn{3}{|c|}{$\begin{array}{l}\text { LE A According to RAPONDA-WALKER and SILLANS (1961: 106) the trunk (of the kapok tree) is some- } \\
\text { times used to make canoes. The kapok is sold on the market. Among the indigenous population, it } \\
\text { is used to stuff cushions and mattresses, or else it is spun to make travelling-bags. The bark of the } \\
\text { young trees, with the thorns removed, is used to make partitions for huts. A decoction of the bark } \\
\text { is used as a an emetic or for enemas. The leaves can be used as an emollient or to soothe neuralgia. } \\
\text { Oil can be obtained from its seeds. This giant plant is regarded by the Blacks as a sacred tree. } \\
\text { When two kapok trees, standing side by side, are seen on the site of ancient villages it is an indi- } \\
\text { cation that twins were born there long ago. It is also the tree that is mainly planted as protecting } \\
\text { fetish and on graves. It is at the foot of these trees that offerings to ancestral spirits or to tutelary } \\
\text { spirits are left. }\end{array}$} \\
\hline
\end{tabular}

Text example 4 


\begin{tabular}{|l|l|l|}
\hline díbogha (+ bogha) [díbòyè] $n$. cl. $5<*$-búga or -búka \\
\hline $\begin{array}{l}\text { Mwîri múdídi ivávégha } \\
\text { (tsi)mbânzi mu úyaaba búkulu } \\
\text { bu bulôngu. }\end{array}$ & $\begin{array}{l}\langle\mathbf{F}\rangle \text { Arbuste dont les râpures } \\
\text { d'écorces fraîches, la poudre de } \\
\text { racines séchées ou encore la dé- } \\
\text { coction des racines est donnée } \\
\text { aux initiés afin qu'ils acquièrent } \\
\text { une connaissance du monde; } \\
\text { raspings of the bark, powder of } \\
\text { the of the roots is given to ini- } \\
\text { tiates in order that they acquire } \\
\text { a knowledge of the world; }\langle\mathrm{T}\rangle \\
\text { iboga (Tabernanthe iboga). }\end{array}$ \\
\hline$\sum \|$ Bamúvegha díbogha. & $\langle\mathbf{F}\rangle$ On lui a donné l'iboga. & $\langle\mathbf{E}\rangle$ He was given iboga. \\
\hline$\sum \|$ Anághólu na díbogha. & $\langle\mathbf{F}\rangle$ L'iboga le fait soûler. & $\begin{array}{l}\langle\mathbf{E}\rangle \text { The iboga has intoxicated } \\
\text { him. }\end{array}$ \\
\hline
\end{tabular}

$\langle\mathbf{F}\rangle$ Arbrisseau des sous-bois de la forêt, l'ibogha fait partie des produits réputés de la pharmacopée traditionnelle gabonaise. Il possède un double usage, médical et magique. Les râpures d'écorce ainsi que les racines de l'arbrisseau se consomment comme fortifiant, aphrodisiaque ou encore comme coupe-faim. À faible dose les racines combattent efficacement les coliques. Les vertus magiques de l'ibogha sont connues des populations locales depuis longtemps. Mais ce n'est que dans ce qu'il convient d'appeler la religion du Bwiti $(\Rightarrow$ Bwîti) que l'ibogha est placé en très haute estime. En effet, c'est l'arbre 'sacré' des adeptes de cette religion. $\Rightarrow$ quot/cit.

Quot/cit D'après RAPONDA et SILLANS (1961: 90), d'un point de vue scientifique "(...) l'iboga est utilisé comme stimulant neuro-musculaire (dépressions et asthénies physiques et intellectuelles); antitoxique (convalescences des maladies infectieuses, intoxications). (...) c'est surtout dans les pratiques fétichistes qu'ils (les indigènes) en font usage (de l'ibogha). C'est en effet la plante magique par excellence des adeptes du Bouitti. Elle sert principalement pour la cérémonie rituelle d'initiation à cette société secrète. L'absorption des râpures d'écorce ou du bois de la racine détermine une sorte d'ébriété, d'hébétude, de torpeur dans les facultés intellectuelles. À doses massives, l'iboga fait perdre la raison, provoque des hallucinations et parfois la mort. L'état de léthargie dû à l'usage immodéré de l'iboga dure 4 à 5 jours pendant lesquels le patient ne prend aucune nourriture."

"(Les adeptes du Bwiti) font également usage d'un breuvage magique confectionné avec les râpures d'écorce de Tabernanthe iboga. Cette mixture les plonge dans un état d'ébriété pouvant aller jusqu'à annihiler momentanément toute notion du monde extérieur. Au cours de cette cérémonie religieuse qui est le Bouïti, on ne se contentait pas d'absorber un tel «léthé»; on y a pendant longtemps procédé à des agapes d'une nature particulière d'où les végétariens devraient probablement être exclus (...) Allons, ne rions donc pas des pratiques de sorcellerie des Noirs d'Afrique car il est bien rare en effet que l'homme, même évolué, néglige le Merveilleux! Nous avons bien aussi nos cartomanciennes, tous les dispensateurs d'horoscope, les voyants, sans compter les sorcières du Moyen Age ..." RAPONDA-WALKER et SILLANS (1961: 32).

〈E Shrubby tree of the undergrowth of the forest, the ibogha forms part of the well-known products of the traditional Gabonese pharmacopoeia. It has a double use, medical and magical. Raspings of the bark as well as the roots of the tree are taken as stimulant, aphrodisiac and hungerdepressant. A small dosage of the roots is an effective remedy for colic. The magical properties of the ibogha have been known to the local community for a long time. But it is only in the so-called Bwiti religion ( $\Rightarrow$ Bwîti) that the ibogha is held in very high esteem. In fact, it is the 'sacred' tree of the adepts of this religion.

Text example 5

These typographical structural elements form part of the rapid access structure of the dictionary (cf. Hausmann and Wiegand 1989: 329). The use of the upside down triangle enables a user who is not interested in the grammatical aspect of the lemma signs mufúma and díbogha, immediately to jump to the upside- 
down triangle. So the dictionary user does not have to read everything until he/she comes to the information on plant uses. From this introductory text, the user is referred to relevant literature in which the lemma sign is discussed at length. According to the approach of Wiegand (1996), the lemma sign mufúma or díbogha is the reference position. The reference entry $\Rightarrow$ quot/cit. (see quotation/citation) consists of a reference marker $(\Rightarrow)$ and an entry indicating the reference address (quot/cit). Given the fact that this mediostructural procedure does not exceed the boundaries of the article, it can be referred to as an internal reference address (cf. Gouws and Prinsloo 1998: 20-22). In addition, both Text examples 5 and 6 have a limited data type.

\begin{tabular}{|c|c|c|}
\hline \multicolumn{3}{|c|}{ ibŭngu ${ }^{1}$ (+ bungu) [ìbŭngù] $n$.cl. $7<<^{*}$-búngu or -bứngu } \\
\hline $\begin{array}{l}\text { Bwâla bu mátengu․ (Bwâla a } \\
\text { búná bwâla bú nyimbí. Bátu } \\
\text { bootsu basăbúmóna. Bwâla bu } \\
\text { bátu báfu kála.) }\end{array}$ & $\begin{array}{l}\langle\mathbf{F}\rangle \text { Village des revenants. (Ce } \\
\text { village est occulte. Par consé- } \\
\text { quent il est invisible pour le } \\
\text { profane. C'est le village des } \\
\text { morts.) }\end{array}$ & $\begin{array}{l}\langle\mathbf{E}\rangle \text { Village of ghosts. (This vil- } \\
\text { lage is regarded as being oc- } \\
\text { cult. It is therefore invisible to } \\
\text { the layperson. It is the village } \\
\text { of the dead.) }\end{array}$ \\
\hline $\begin{array}{l}\sum \| \text { Anámúbóka anámútúúla } \\
\text { mo ibŭngu yandi. }\end{array}$ & $\begin{array}{l}\langle\mathbf{F}\rangle \text { Il l'a tué et l'a mis dans son } \\
\text { village des revenants. }\end{array}$ & $\begin{array}{l}\langle\mathbf{E}\rangle \text { He killed him and put him } \\
\text { in his village of ghosts. }\end{array}$ \\
\hline fumu ibŭngu Fumu nyimbi. & $\begin{array}{l}\langle\mathbf{F}\rangle \text { Le maître du village des } \\
\text { fantômes. }\end{array}$ & \\
\hline $\begin{array}{l}\sum \| \text { l| (Mangúmba.) Fumu ibŭngu } \\
\text { ákâ? }\end{array}$ & $\begin{array}{l}\langle\mathbf{F}\rangle \text { Où est la personne respon- } \\
\text { sable de la veillée (mortuaire)? }\end{array}$ & \\
\hline$\sum||$ Mona fumu ibŭngwa! & $\begin{array}{l}\langle\mathbf{F}\rangle \text { Voici la personne respon- } \\
\text { sable de la veillée! }\end{array}$ & \\
\hline \multicolumn{3}{|c|}{$\begin{array}{l}\nabla\langle\mathbf{F}\rangle \text { Le maître du village des revenant utilise les esprits de ceux et celles dont il/elle a tué et } \\
\text { asservi pour accéder à une position sociale élevée. Cette quête d'un meilleur statut social se traduit } \\
\text { souvent par une ascension fulgurante. Ces esprits sont également utilisés comme gardes du corps } \\
\text { et hommes de main. Le propriétaire d'un village de fantômes jouit de la protection surnaturelle } \\
\text { des esprits dont il/elle a le contrôle. Ces esprits passent pour commettre des assassinats ou crimes } \\
\text { rituels au sein des populations, faisant ainsi passer en leur maître la force vitale des gens qu'ils } \\
\text { mettent à mort. Mais les privilèges dont le maître d'un village de fantômes jouit ont un prix. Ce } \\
\text { dernier pour se concilier ces esprits, il se doit de leur offrir annuellement un sacrifice humain. En } \\
\text { se refusant à honorer les termes de ce contrat, le propriétaire des dits-esprits s'expose à leur colère } \\
\text { impitoyable. }\end{array}$} \\
\hline \multicolumn{3}{|c|}{$\begin{array}{l}\langle E\rangle \text { The master of a village of ghosts uses the spirits of the people he/she has killed to achieve a } \\
\text { high social position. This quest for a better social status often results in a quick ascent. These spir- } \\
\text { its are also used as bodyguards and killers. The owner of a village of ghosts enjoys supernatural } \\
\text { protection from the spirits he/she has under control. These spirits are believed to commit assassi- } \\
\text { nations or ritual crimes amongst the population, in this way causing the vital force of the people } \\
\text { they kill to be passed on to their master. However, the privileges enjoyed by a master of a village } \\
\text { of ghosts bears a price. The latter has annually to provide these spirits with a human sacrifice. By } \\
\text { refusing to respect this contract, the owner of these spirits exposes him-/herself to their merciless } \\
\text { anger. }\end{array}$} \\
\hline
\end{tabular}

Text example 6

The knowledge, beliefs, and practices of the Yilumbu society are extensively reflected in these articles. However, in the case of the article of the lemma díbogha in particular, reservations can be made by target users with regard to 
an unbalanced presentation of data. It appears that in the encyclopedic section presenting excerpts from relevant literature dealing with the treated lexical item, the focus is on dictionary users who are familiar with French. Although this is detrimental to the English user, this discrepancy may be motivated on the grounds of user proficiency. Given the fact that the planned dictionary is primarily aimed at meeting the needs of Balumbu mother-tongue speakers with a relative good command of French, these target users should get the primary focus.

In the treatment of the article in Text example 6, bwâla bu máteng $u^{\circ}$ (village of ghosts) is the real paraphrase of the meaning of the lemma ibŭngu. The sentences Bwâla a búná bwâla bú nyimbí, Bátu bootsu basăbúmóna, and Bwâla bu bátu báfu kála are explanatory additions and marked as such by the use of parentheses. In addition to the foregoing, the symbol ${ }^{\circ}$ after the lexical item mátengu (ghosts) means that this word will be explained somewhere else in the planned dictionary. What follows after the English co-text example is of an ethnographical nature. This encyclopedic entry in both French and English gives the user more information regarding the cultural context of the lemma ibŭngu ${ }^{8}$

An implicit presentation of culture-bound lexical items may be acceptable for those who might have a sound knowledge of their mother tongue and native culture, but for those having a passive knowledge of Yilumbu this may prove to be highly problematic. That is why the lexicographer must make the data maximally explicit in the lexicographic text. As learners are also dealt with in this research, the lexicographer has to be well aware of the needs of these learners. The planned dictionary has to be user-orientated.

With regard to the dictionary article given as Text example 7, a lot of examples of sublemmatic addressing can be found, in particular in the section dealing with a niched paradigm of compounds with ngwîsi as first component, introduced by the symbol $\mathbf{m}$. The ordering within this sinuous lemma file is strictly alphabetic and very user-friendly. In fact, each compound is followed by an explanation in the target languages so that the user gets a better idea of the meaning. As long as the explanation of the meaning continues, there is also a transfer of focus from the source to the target language. The purpose of the use of non-typographical markers in the case of the entries coupure de cordes, levée de terre and port de deuil which have been made "visual" to the dictionary-user by the use of bold characters, and indicated by (frGab), is that these lexicographic units are the so-called culture-bound elements in Gabonese French.

In rural areas, the corpse of a person who has passed away can be kept for two days on the maximum. By the third day it has to be buried. If the person who passed away was a married man, the tradition requires his widow(s) to sleep on leaves of the banana-tree (Musa paradisiaca) for four days. On the fifth day a ceremony is organised in order to allow the widow(s) to sleep on a mat on the ground. Two weeks after the burial, a ceremony called mangumba is arranged in order to pacify the spirit of the deceased. During this ceremony, held at night, songs and dances are performed. In the morning, the cutting of 
the pall that people have around their wrists as sign of mourning takes place. This is referred to as the "coupure de cordes" in Gabonese French. Then members of the family, the children of the deceased man and his widow(s) have to undergo purificatory rites. According to custom, an uncleanness caused by death is believed to rest on widows, in particular, after the death of the husband. This uncleanness has to be washed away by a ritual bath before the members of the family can wear the mourning of the deceased (referred to as "port de deuil" in Gabonese French). This ceremony also serves as a rising from the earth which is referred to as "levée de terre" in Gabonese French. For this part of the funeral rite, the widow's bed (the sleeping mat) is put upside down (uwúdigha tângi) which literally means that the widow is now allowed to sleep on a bed. Finally, after a year, a celebration is held officially to end the mourning period ("retrait de deuil" in Gabonese French).

\begin{tabular}{|c|c|c|}
\hline \multicolumn{3}{|c|}{ ngwîsi (+gwisi) [ygwîsì] (aussi/also ngúsi) n. cl. 9/10< < -gụisisi } \\
\hline Muyínu o dúfu ná gho báyi- & & $\begin{array}{l}\langle\mathbf{E}\rangle \text { Customary dance or cere- } \\
\text { mony for tutelary spirits. } \Rightarrow \\
\text { ngwêdi. }\end{array}$ \\
\hline $\begin{array}{l}\text { III (Ghâng.) Yoonu batsísi } \\
\text { ngwîsi i mfúúmbi Mákaya. } \\
\text { (Men.) Yoonu batsívanga nngwî- } \\
\text { si i mfúúmbi Mákaya. }\end{array}$ & $\begin{array}{l}\langle\mathbf{F}\rangle \text { Hier, ils ont organisé la } \\
\text { cérémonie (mortuaire) de feu } \\
\text { Makaya. }\end{array}$ & $\begin{array}{l}\langle\mathbf{E}\rangle \text { Yesterday they organised } \\
\text { the late Makaya's (funeral) ce- } \\
\text { remony. }\end{array}$ \\
\hline $\begin{array}{l}\sum \| \text { (Ghâng.) Ngwîsi be yína } \\
\text { utsíwiítsila pwééla bátu. (Men.) } \\
\text { Ngwîsi be yína iyétsíla bátu ba } \\
\text { bînga. }\end{array}$ & $\begin{array}{l}\langle\mathbf{F}\rangle \text { Beaucoup de personnes ont } \\
\text { assisté à cette cérémonie (mor- } \\
\text { tuaire). }\end{array}$ & $\begin{array}{l}\langle\mathbf{E}\rangle \text { A lot of people attended } \\
\text { this (funeral) ceremony. }\end{array}$ \\
\hline \multicolumn{3}{|c|}{$\begin{array}{l}\text { ngwîsi dúfu est une veillée mortuaire/ is a funeral wake; ngwîsi i Mábaantsi rite de passage } \\
\text { statutaire qui permet aux jeunes filles de passer de l'âge de puberté à l'âge adulte. Le rite a été pra- } \\
\text { tiqué à l'origine par les femmes. Aujourd'hui, les Mabaantsi est une société secrète initiatique } \\
\text { mixte/ is a rite of passage that allows girls to pass from puberty to become adults. The ritual was originally } \\
\text { practised by women. Today the Mabaantsi is a mixed secret initiation society; (Men.) ngwîsi i mîts } \\
\text { ( } \Rightarrow \text { (Ghâng.) ngwîsi misînga) est une cérémonie funéraire marquée par la (frGab) coupure de } \\
\text { cordes provenant du drap funéraire ou mortuaire que les gens portent autour des poignets en } \\
\text { signe de deuil. Cette cérémonie est également organisée en guise de (frGab) levée de terre et elle } \\
\text { annonce éventuellement le (frGab) port de deuil/ is a funeral ceremony marked by the cutting of the } \\
\text { pall people bear around their wrists as sign of mourning. This ceremony also serves as a rising from the } \\
\text { ground and it eventually announces the bearing of the mourning; ngwîsi Mughulu est une société } \\
\text { secrète et initiatique qui viendrait des Bisira/ is a secret initiation society believed to have come from the } \\
\text { Bisira; ngwîsi Mulóghu est une société secrète et initiatique. Lorsqu'une personne de sexe feminin } \\
\text { est frappée par le Mulóghu, elle tombe ordinairement dans une espèce de transe ( } \Rightarrow \text { utútúgha), un } \\
\text { genre de folie qui est supposée causée par l'esprit des ancêtres. Seul le père (au sens que ce terme a } \\
\text { dans les langues gabonaises) peut apaiser la colère de l'esprit des morts. C'est pour cette raison } \\
\text { que les gens font généralement appel à lui pour un rituel de délivrance consistant simplement à } \\
\text { des paroles de bénédiction/ is a secret initiation society. When a female person is struck by the Mulóghu } \\
\text { she usually falls in a kind of trance ( } \Rightarrow \text { utútúgha), a sort of madness assumed to be caused by the ancestra } \\
\text { spirits. Only the father (in the sense that this word has in the Gabonese languages) can appease the anger of } \\
\text { the spirits of the dead. It is for this reason that people generally call upon him to perform a ritual of deliver } \\
\text { ance that merely consists of words of blessing. }\end{array}$} \\
\hline
\end{tabular}

Text example 7 


\section{On the metalanguage used in the proposed article structures}

\section{- The problem}

If French or English is chosen as the metalanguage (e.g. the language used for the texts of definitions as well as notes in the form of labels) of the planned dictionary, the latter will be less informative for Yilumbu speakers than their French and English counterparts whose language will predominantly be used to reflect on the meaning of lexical items as well as the culture that underlies them.

\section{- Decision taken}

The solution would lie in the combination of a few standardised sets of abbreviations in the form of labels and the use of Yilumbu on the metalinguistic level. With regard to French and English, the standardised sets of abbreviations (in the form of labels) used in these two proposed articles mainly include the use of the part of speech label $n$. (nom/noun). Given the fact that the primary target user group of the planned dictionary is the Balumbu mother-tongue speakers, the metalanguage for the paraphrases of meaning, the so-called diatopic or regional labels such as (Ghâng.) and (Men.), sphere of usage labels such as (Mangúmba), and encyclopedic information in synopsis articles addressed at mother-tongue speakers should be in Yilumbu. This is important and can be motivated by what follows. With regard to dictionary typology, Zgusta (1989: 71) has mentioned the role of a subcategory of dictionaries instrumental in the revival of languages. Given the fact that nowadays the Gabonese in general and the Balumbu in particular live in a society where all aspects of life have become increasingly westernised, the cultural dimension must be said to be one of the areas that really need to be examined in more detail. Thus all attempts towards preventing the indigenous cultures from disappearing (both at state or individual level or by means of a dictionary, for example) may be referred to as culture revival.

\section{On the access structure of the proposed article structure}

\section{- The problem}

Dictionaries are known to present great access problems to users. That is why one of the challenges facing lexicographers is to devise a user-friendly access structure enabling inexperienced dictionary users to maximally benefit from using a particular dictionary.

\section{- Decisions taken}

Given the fact that dictionary users usually experience great difficulties in 
understanding the boundaries of a given entry, the definition in particular, a decision has been taken to make use of the so-called ordering devices to mark the boundaries of each simple entry. For example, all the data occurring between the following structural indicators $(\downarrow)$ represents the paraphrase of meaning of the treated lexical item. On the same principles, co-text examples are introduced by the structural indicator $(\Sigma \mid l)$. In addition and with reference to Wiegand's concept of microarchitecture, each piece of data type starts on a new line. Such a foundation is likely to greatly improve the access structure of the planned dictionary because the user perceives each data type clearly. To be effective, these metalexicographic procedures must be reflected on in the compulsory users' guide of a particular dictionary. In present-day lexicography more and more proposals are made towards introducing a component "dictionary using skills" at school's level that will equip users with the necessary expertise to use dictionaries more efficiently as sources of reference.

\section{Conclusion}

Devising the microstructure of a dictionary is one of the greatest responsibilities of the lexicographer, especially when it comes to the structure of a specific category of articles, namely synopsis articles as opposed to single articles. The metalexicographical discussion above shows that synopsis articles have a more general use than its restricted application in LSP dictionaries. In accordance with the data distribution structure of the planned dictionary, synopsis articles should not only include scientific terminology but also cultural lexical items. In the traditional approach, synopsis articles are characterised by a low density of data categories because data types such as the items giving the translation equivalent, the etymology or the usage example are not so important. The focus is usually on extra-linguistic aspects.

The lexicographic treatment presented in synopsis articles usually results in lengthier articles with a variety of data types and search zones that could impede the successful retrieval of the information users are seeking. Therefore there should be a system of contextual entries to assist users in the most effective way (cf. Gouws 1999: 47). In addition, mediostructural representations, and access and addressing procedures should also come into play. As far as the addressing structure is concerned, the distant addressing prevailing between co-text entries and paraphrases of meaning/translation equivalents in unintegrated microstructures should lead the lexicographer to use an integrated microstructure in synopsis articles. However, a semi-integrated microstructure could be used in synopsis articles of which the lemma sign is of a polysemous nature. Because of a relation of distant addressing between a co-text entry and the relevant paraphrase of meaning/translation equivalent in the second section of a semi-integrated microstructure, the lexicographer will still have to provide users with contextual data enabling them to disambiguate the different senses presented in the article. Moreover, by providing users with a list (in the 
back matter section) of all the items which are treatment units in the central list's synopsis articles, the particular dictionary will be polyfunctional and polyaccessible.

\title{
Abbreviations, Symbols and Labels Used in the Text Examples
}

\author{
$\langle\mathbf{F}\rangle$ : French \\ $\langle$ E): English \\ $\langle\mathrm{T}\rangle$ : Translation equivalent(s)/traduction(s) \\ $1,2,3,4, \ldots$ These are markers of polysemy.
}

- These mark the boundaries of the definition.

n.: noun

cl.: class

$<$ : comes from

* : proto-Bantu reconstruction

$\sum \|$ : This introduces examples.

$\mathbf{\nabla}$ : This marks a specific article slot in which extra-linguistic data are given.

$\Rightarrow$ : Reference marker

${ }^{\circ}$ : When given after a particular lexical item, this symbol indicates that the lexical item in question is explained somewhere else in the specific dictionary.

- : This introduces a sublemma.

Quot/cit: Quotation/citation

(apoc.): apocope

(by ext.): by extension

(chrét.): religion chrétienne

(Chris.): Christian religion

(frGab): Gabonese French

(Ghâng.): Yilumbu yi ghângu

(Mangúmba): Dance held at funerals

(Men.): Yilumbu yí menaáne

(o ingánga): Christian religion (lit.: "in church")

(par ext.): par extention

\section{Acknowledgement}

Comments, discussions and suggestions from Prof. Sven Tarp, Prof. R.H. Gouws and Dr J.C.M.D. du Plessis on an earlier version of this article are greatly appreciated.

\section{Endnotes}

1. In this article I use the official Gabonese spelling and not the traditional semiphonetic spell- 
ing employed by Guthrie, Jacquot, Kwenzi-Mikala and others. The underlined $\underline{\mathbf{e}} \underline{\underline{o}}$ and $\underline{\mathrm{n}}$ represent $[\varepsilon],[\supset]$ and $[\eta]$ respectively. The phonetic sound [ə] is represented by the symbol $ə$ in Gabonese orthography. However, for phonological and practical reasons I have chosen to represent it by a, as in Make.

The accent signs on vowels indicate tones (for a description, see Afane Otsaga 2002: 76-79).

2. It must be kept in mind that the term "African languages", used here for the sake of sensitivity with respect to the term "Bantu languages" in the South African context, has a wider application than languages belonging to the "Bantu language family", such as the Gabonese languages.

3. This information comes from a class lecture of Prof. R.H. Gouws.

4. Some scholars in the field of lexical semantics (cf. Lehrer 1974 and Lyons 1977), have drawn the attention to the existence of lexical gaps. A distinction is usually made between linguistic and referential gaps. According to Gouws (1996: 25-26), a linguistic gap exists where in two different speech communities the speakers of a language $X$ do not have a word for an object, which only exists in language $Y$ and vice versa. A referential gap occurs where a lexical item from language $X$ does not have a translation equivalent in language $Y$ simply because the speakers of that language are not familiar with the referent in question. In this case, lexicographers quite often use a paraphrase of meaning or a loan word as a surrogate equivalent. The lack of lexical items in e.g. English or French to offer as translation equivalents for the Yilumbu "mupééyi" (wild mangoes that are pounded without being previously dried) and "ngwâmba" (absence of meat in the homes) represent a referential gap because both speakers of French and English are not familiar with the referents of these lexical items.

5. The use of the inserted inner text and other typographical features is not from Kritzinger et al. but from the author.

6. Cf. Naden 1996: 87.

7. The proto-Bantu reconstructions in Text examples 4-7 come from Nsuka-Nkutsi (1980).

8. I gladly acknowledge information obtained from Guy-Roger Mihindou as far as illustrative examples given in the treatment of the articles of lemmata ibŭngu and ngwîsi are concerned.

\section{Bibliography}

Afane Otsaga, Thierry. 2002. Les tons dans les dictionnaires de langues gabonaises: situations et perspectives. Lexikos 12: 75-89.

Bergenholtz, H., S. Tarp and H.E. Wiegand. (1999) Datendistributionsstrukturen, Makro- und Mikrostrukturen in neueren Fachwörterbüchern. Hoffmann, L., H. Kalverkämper, H.E. Wiegand (Eds.), together with Ch. Galinski and W. Hüllen. Fachsprachen. Ein internationales Handbuch zur Fachsprachenforschung und Terminologiewissenschaft / Languages for Special Purposes. An International Handbook of Special-Language and Terminology Research. Berlin/New York: De Gruyter.

Gouws, R.H. 1996. Bilingual Dictionaries and Communicative Equivalence for a Multilingual Society. Lexikos 6: 15-31.

Gouws, R.H. 1999. A Theoretically Motivated Model for the Lexicographic Processes of the National Lexicography Units. Research report submitted to the Pan South African Language Board.

Gouws, R.H. 2002. Niching as a Macrostructural Procedure. Lexikos 12: 133-158.

Gouws, R.H. and D.J. Prinsloo. 1998. Cross-Referencing as a Lexicographic Device. Lexikos 8: 1736.

Hausmann, F.J. and H.E. Wiegand. 1989. Component Parts and Structures of General Monolingual 
Dictionaries: A Survey. Hausmann, F.J. et al. (Eds.). 1989-1991. Wörterbücher. Ein internationales Handbuch zur Lexikographie / Dictionaries. An International Encyclopedia of Lexicography / Dictionnaires. Encyclopédie internationale de lexicographie: 328-360. Berlin: Walter de Gruyter.

Kritzinger, M.S.B. et al. (Eds.). 198613. Groot Woordeboek. Afrikaans-Engels/Engels-Afrikaans. Pretoria: Van Schaik.

Lehrer, A. 1974. Semantic Fields and Lexical Structures. Amsterdam/London: North-Holland Publishing Company.

Lyons, J. 1977. Semantics. Volume 1. Cambridge: Cambridge University Press.

Naden, Tony. 1996. Ancestor Non-worship in Mamprali. Lexikos 6: 71-103.

Nsuka-Nkutsi, F. 1980. Quelques reflexes du proto-Bantu en Punu. Nsuka-Nkutsi, F. (Éd.). 1980. Éléments de description du Punu: 129-179. Lyons: PUL.

Nyangone Assam, B. and P.A. Mavoungou. 2000. Lexicography in Gabon: A Survey. Lexikos 10: 252-274.

Prinsloo, D. J. and R.H. Gouws. 2000. The Use of Examples in Polyfunctional Dictionaries. Lexikos 10: 138-156.

Raponda-Walker, A. and R. Sillans. 1961. Les plantes utiles du Gabon: essai d'inventaire et de concordance des noms vernaculaires et scientifiques des plantes spontanées et introduites du Gabon. Paris: Lechevalier.

Smit, M. 1996. Wiegand's Metalexicography as a Framework for a Multilingual, Multicultural, Explanatory Music Education Dictionary for South Africa. Unpublished D.Litt. Thesis. Stellenbosch: University of Stellenbosch.

Tomaszczyk, J. 1983. The Culture-Bound Element in Bilingual Dictionaries. Hartmann, R.R.R. (Ed.). LEXeter '83 Proceedings: 289-297. Tübingen: Max Niemeyer.

Wiegand, H.E. 1978. Lexikographische Praxis — vom Standpunkt unterschiedlicher Wörterbuchtypen und Wörterbuchkonzepte. Zeitschrift für germanistische Linguistik 6: 326-330.

Wiegand, H.E. 1996. Über die Mediostrukturen bei gedruckten Wörterbüchern. Zettersten, A. and H. Pedersen (Eds.). Symposium on Lexicography VII: 11-43. Tübingen: Max Niemeyer.

Wiegand, H.E. 1999. Semantics and Lexicography. Selected Studies (1976-1996). Edited by Anntje Immken and Werner Wolski. Tübingen: Max Niemeyer.

Zgusta, L. 1987. Translational Equivalence in a Bilingual Dictionary. Dictionaries 9: 1-43.

Zgusta, L. 1989. The Role of Dictionaries in the Genesis and Development of the Standard. Hausmann, F.J. et al. (Eds.). 1989-1991. Wörterbücher. Ein internationales Handbuch zur Lexikographie/ Dictionaries. An International Encyclopedia of Lexicography / Dictionnaires. Encyclopédie internationale de lexicographie: 70-77. Berlin: Walter de Gruyter. 